\title{
Quality assessment of inhospital patients unable to speak who use alternative and extended communication
}

\author{
Avaliação da qualidade intra-hospitalar de pacientes impossibilitados \\ de falar que usam comunicação alternativa e ampliada
}

Fabrício Marinho Bandeira' ${ }^{1}$, Flávia Perassa de Faria ${ }^{1}$, Everaldo Batista de Araujo ${ }^{1}$

\begin{abstract}
Objective: To implement the use of alternative communication boards in patients hospitalized and unable to communicate by speech. Methods: A descriptive study with a sample of 30 patients hospitalized and unable to communicate by speech. Boards were made with Boardmaker ${ }^{\circledR}$ Software that consists of a graphical database containing Pictorial Communication Symbols. To assess the quality of life of these patients, the Portuguese SF-36, a translated version of the Medical Outcomes Study, was applied before and after the study. Results: We found that all domains of the SF-36 showed changes after the application of communication boards. We observed that the minimum score was assigned to the mental health domain, whereas the most affected and with greatest involvement and least compromise was the overall health status. Conclusion: The quality of life assessment of patients showed improvement with the use of communication boards, demonstrating the importance and necessity of communication between the patient and staff and the patient and family members.
\end{abstract}

Keywords: Disabled persons; Communication barriers; Quality of life; Intensive care units; Questionnaires

\section{RESUMO}

Objetivo: Implementar o uso de pranchas de comunicação alternativa em pacientes hospitalizados e impossibilitados de se comunicarem pela fala. Métodos: Estudo descritivo com amostra de 30 pacientes hospitalizados e impossibilitados de se comunicarem pela fala. Foram confeccionadas pranchas por intermédio do software Boardmaker ${ }^{\circledR}$ que consiste em um banco de dados gráfico contendo Símbolos de Comunicação Pictórica (Picture Symbols Communication). Para avaliar a qualidade de vida desses pacientes, foi aplicado, antes e após o estudo, o questionário SF-36, versão em português do Medical Outcomes Study traduzido. Resultados: Verificou-se que todos os domínios do SF-36 apresentaram alterações após a aplicação das pranchas de comunicação. Observou-se que a mínima pontuação foi atribuída ao domínio "saúde mental", sendo o domínio "estado geral de saúde" o mais afetado e com menor comprometimento. Conclusão: A avaliação da qualidade de vida dos pacientes estudados apresentou melhora com 0 uso das pranchas de comunicação, demonstrando a importância e a necessidade da comunicação entre paciente-equipe e paciente-familiar.

Descritores: Pessoas com deficiência; Barreiras de comunicação; Qualidade de vida; Unidades de terapia intensiva; Questionários

\section{INTRODUCTION}

Communication is a basic need among humans. It is necessary in relationships, and represents a fundamental aspect for survival. From its birth, a child uses crying and laughing to express his/her wishes. He/she learns to talk little by little, utilizing gestures and postures, maintaining contact with those around him/her and becoming active in the surroundings ${ }^{(1,2)}$.

In Brazil, the work of alternative communication has been happening in rehabilitation centers, private medical offices, and in universities ${ }^{(3)}$. According to the United Nations (UN), there are approximately 500 million people in the world who cannot express themselves through speech, and $80 \%$ of them live in developing countries such as Brazil. Based on data from the 2005 Census, 24.5 million Brazilians, which represent 14.5\% of the population, have such deficiencies. This increase has occurred due to the change in data collection instruments that currently follow the recommendations of the World Health Organization (WHO) $)^{(2,3)}$.

Oral communication characterizes the human condition. Speech associated with gestures, facial, and body expressions, enables communication with other people by means of the expression of needs, desires, and opinions. When a person is temporarily or definitively impeded of communicating

\footnotetext{
Study carried out at Hospital Brasília - Brasília (DF), Brazil.

${ }^{1}$ Hospital Brasília - Brasília (DF), Brazil.

Corresponding author: Fabricio Marinho Bandeira - QNL 30 VIA LN 30, casa 32 - Taquatinga - Norte - CEP 72160-300 - Brasilia (DF), Brazil - Tel.: (61) 9927-7332 - E-mail: fabriciomarinho3@hotmail.com

Received on: Apr 26, 2011 - Accepted on: Oct 25, 2011

Conflict of interest: none
} 
by speech, they need an alternate form to carry out this function. Augmentative and Alternative Communication (AAC) unites other forms of communication, such as the use of gestures, sign language, facial expressions, use of boards with the alphabet or pictographic symbols, and even the use of more sophisticated systems, such as digitized (recorded) or synthesized speech communication devices and computers ${ }^{(4)}$.

In an Intensive Care Unit (ICU), many patients seem incapable of communicating. The reasons are varied, and may include patients who are intubated or have a tracheostomy, patients under sedation, with sequelae of cerebrovascular accidents (CVA), or yet, with preexisting communication difficulties. This difficulty to communicate, regardless of the duration, has been identified as one of the most frustrating and stressing aspects of the $\operatorname{ICU}^{(5,6)}$.

This difficulty may compromise the patient-staff or patient-family relationship, resulting in frustrated, nervous, anxious, agitated, and depressed patients ${ }^{(6)}$.

The perception of day and night is hindered in the ICU, which has activity non-stop and normally is a completely closed air-conditioned environment with no windows. There are constantly professionals in the patient's room coming and going, the televisions remain turned on, and people speak in loud voices; many times there is no visible clock, making it more difficult for the patient to keep track of time and space, as they don't know if it's time to go to sleep or wake up, if bath time is near, or when the staff will change shifts ${ }^{(5)}$.

Investigations have been made with the intention of offering communication alternatives to patients with transient or permanent difficulties in oral communication. The resources utilized may be simple or complex technology. With the goal of amplifying the possibilities of communication, various reception and transmission methods have been used over the years with non-vocal individuals, such as sign language used by the hearing-impaired, and Braille script, the alternative writing method for the blind ${ }^{(6)}$.

The American Speech-Language-Hearing Association (ASHA) defines AAC as an area of clinical and educational practice, and of research for therapists who try to compensate and facilitate the deficiencies and incapacity of individuals with severe disorders of expressive communication and/or comprehension ${ }^{(7)}$. The AAC seeks methods that help the individual who cannot have functional speech. The term "alternative" is used in reference to all that is alternative to words, such as figures, drawings, and symbols ${ }^{(8)}$.

Boardmaker ${ }^{\circledR}$ is a graphic databank that consists of a simple and low-cost device made of paper and laminated with plastic to facilitate cleaning and increase its durability. It contains topics related to communication with basic symbols of the hospital procedures that allow patients to ask questions and get clarification on their situations. This program is presented in Portuguese, which allows one to prepare boards with professional quality in minutes; to locate and apply symbols and images (colored or black and white); to edit the images as to size and spacing; to print and/or save the communication board for future use; to create theme or work sheets, pictorial instruction lists, reading books, journals/newspapers, and posters ${ }^{(9)}$.

The communication boards may contain various items of information, depending on the age of the patients, their level of comprehension, their level of consciousness, the activities programmed for that day, the hygiene and feeding routing, besides recording important activities that may occur without prior scheduling, and may contain letters for the patient to make comments and/or ask questions. The objective of the activity board is to diminish the patient's anxiety as to procedures he/she will be submitted to and to help in the process of orientation and programming his/her day ${ }^{(7,9)}$.

To evaluate quality of life, the Medical Outcomes Study 36-Item Short-Form Health Survey (SF-36) ${ }^{(10)}$ was used, which among us was translated and validated by Ciconelli in $1997^{(11)}$. It is a generic questionnaire, self-applied, easy to use and comprehend, with concepts non-specific for a given age, disease, or treatment group. It takes into consideration the perception of individuals as to their own health status ${ }^{(10-12)}$.

The SF-36 is made up of 36 items, encompassing 8 scales or components: role - physical (RP, 10 items); aspects: physical (4 items), social ( 2 items), and emotional (3 items); bodily pain ( 2 items); general health $(\mathrm{GH}, 5$ items); vitality (4 items); mental health (MH, 5 items), and one more assessment question to compare current health conditions and those of one year before. It evaluates both the negative and positive aspects of health. Data are evaluated based on the transformation of the answers into a 0 to 100 scale for each component, and there is no one value that summarizes the entire assessment, resulting in a "better" or "worse" GH condition ${ }^{(11,13)}$.

\section{OBJECTIVE}

To implement the use of alternative communication boards (a type of chart) with patients who are hospitalized and incapable of communicating through speech.

\section{METHODS}

This is a descriptive study carried out in patients who are hospitalized and incapable of communicating by speech. Boards (a type of chart) were made using the Boardmaker ${ }^{\circledR}$ software. 
The present study was approved by the Ethics and Research Committee of the Universidade Católica de Brasília (UnB) under CEP/UCB \# 052 /2011 and developed by the Hospital Brasília, in Brasília (DF). All the study participants, or the persons responsible for them, read and signed the Informed Consent Form, thereby agreeing to participate in the study.

The sample was made up of 30 adult patients of both genders, with diseases that made them incapable of communicating by speech, with ages that varied from 20 to 70 years. For orientation regarding day and night, digital and analogic clocks (Ibraclok ${ }^{\circledR}$ ) were used, with large hands and numbers that could be seen by the patient from a distance, besides symbols that complemented the information on the period of the day (morning, afternoon, or evening).

With the intention of evaluating the quality of life of these patients before and after the collection, the Portuguese version or the SF-36 questionnaire of the Medical Outcomes Study 36-Item Short-Form Health Survey 10, was applied, which had been translated and validated by Ciconelli ${ }^{(11)}$.

The inclusion criteria adopted were a) adult patients hospitalized at the Hospital Brasília aged between 20 and 70 years, who were incapable of communicating by speech; b) whose families showed interest in having their family member included in the said study; c) Informed Consent Form signed by the patient or the person responsible for him/her. Excluded from the study were a) patients younger than 20 years of age; b) who were not able to conclude the tests proposed or who refused to participate in the research; c) were haemodynamically unstable; d) were sedated or unconscious.

Patients were interviewed and evaluated by two duly trained researchers for all the stages of the study. Initially, a brief interview was conducted with these patients or with their families, in order to obtain information as to the time and form of progression of the disease that hindered them from communicating through speech, whether temporarily or permanently. Other socio-demographic and personal data were collected from the patient charts.

The communication boards were prepared according to the needs of each study patient. After they had been made, they were printed and laminated with plastic to be presented to the patients, who were positioned in the bed with the headboard elevated between 30 and $45^{\circ} \mathrm{C}$ so that they could best visualize the boards (Figure 1).

For the statistical treatment, a descriptive analysis was made of the data and the independent $t$ test was used to compare the mean of the quality of life of the subjects, and Spearman's test was

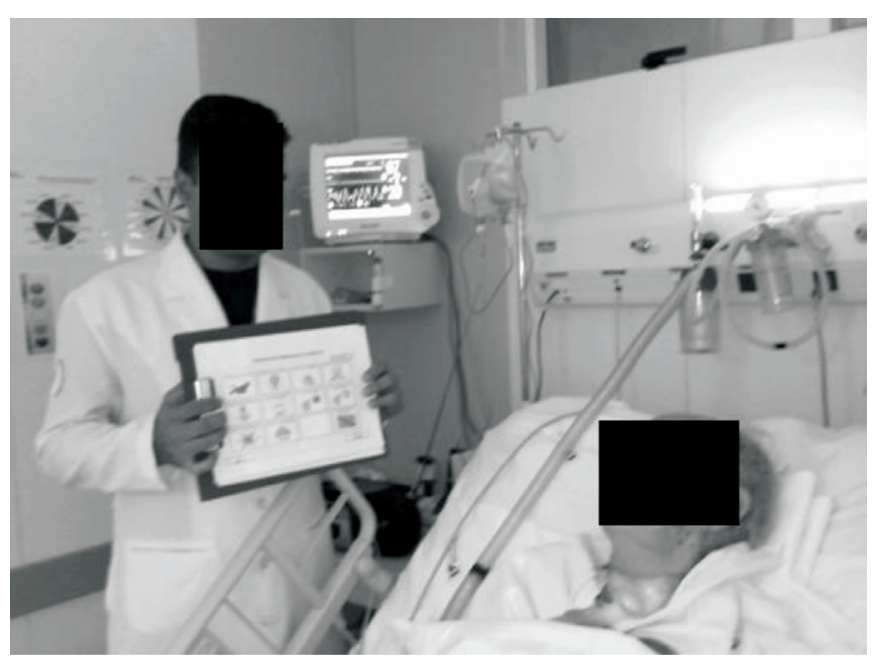

Figure 1. Applying the communication board

utilized to evaluate the correlation among domains of the SF-36 questionnaire. Data were plotted with Excel and Statistical Package for the Social Sciences (SPSS) version 14.0 software, both compatible with Windows, and the level of significance adopted was $\mathrm{p} \leq 0.05$.

\section{RESULTS}

The sample was composed of 30 patients, where $80 \%$ were men, and the mean age of the entire group was $43.56 \pm 15.14$ years. When stratified for gender, the group of men had a mean age of $45.67 \pm 13.39$ years, while for the group of women it was $40.41 \pm 17.56$ years (Table 1).

Table 1. Distribution of sample per gender and age group

\begin{tabular}{lccc}
\hline & & Male & Female \\
\hline Sample & 30 & 18 & 12 \\
Age group & 20 to 70 years & 21 to 67 years & 22 to 70 years \\
Mean age & 43.56 years $( \pm 15.14)$ & 45.67 years $( \pm 13.19)$ & 40.41 years $( \pm 17.56)$ \\
\hline
\end{tabular}

The SF-36 questionnaire domains were applied for all patients, before and after the use of the communication board. The mean values identified for each domain can be seen on table 2, which also shows the domains in which there was statistical significance.

The results of the statistical analysis of questionnaire SF-36 show that among the 30 patients evaluated, all domains were affected both before and after the use of the communication boards. The domains Functional Capacity (FC), limitations due to physical aspects (LPA), overall health status (OHS), and Mental Health showed an increase after application of the board, but they did not display a statistically significant difference. The values found for the domains "social aspects" (SA), "social 
Table 2. Mean and significant values obtained for each domain of the SF-36 questionnaire, before and after the application of the communication board

\begin{tabular}{lcc}
\hline SF-36 Domain & $\begin{array}{c}\text { Communication boards } \\
\text { Before }\end{array}$ & $\begin{array}{c}\text { Communication boards } \\
\text { After }\end{array}$ \\
\hline & Mean \pm SD & Mean \pm SD \\
Functional capacity (FC) & $54.12 \pm 4.64$ & $56.5 \pm 5.67$ \\
Limitations due to physical aspects (LPA) & $57.8 \pm 5.11$ & $61.2 \pm 4.65$ \\
Pain (PAIN) & $52.5 \pm 3.42$ & $56.5 \pm 4.32$ \\
Overall health status (OHS) & $64.9 \pm 4.23$ & $67.3 \pm 4.32$ \\
Social vitality (V) & $42.94 \pm 5.93$ & $60.1 \pm 5.32$ \\
Social aspects (SA) & $52.4 \pm 3.67$ & $63.4 \pm 4.34$ \\
Limitations of the emotional aspects (LEA) & $47.2 \pm 4.87$ & $59.5 \pm 5.43$ \\
Mental health (MH) & $52.5 \pm 2.43$ & $55.2 \pm 4.35$ \\
\hline
\end{tabular}

SD: standard deviation; * $p<0.05$.

Table 3. Spearman correlation (RS) - analysis of the domains vitality (V) and limitations of the emotional aspects (LEA)

\begin{tabular}{lcccc}
\hline Spearman correlation & & Feeding & Communication \\
\hline Spearman rho & Vitality (V) & Correlation coefficient & 1.000 & 0.832 \\
& & Sig. (2-tailed) & 0.0 & 0.000 \\
& & $n$ & 16 & 16 \\
& Limitations of the emotional aspects (LEA) & Correlation coefficient & 0.832 & 1.000 \\
& & Sig. (2-tailed) & 0.000 & 16 \\
\hline
\end{tabular}

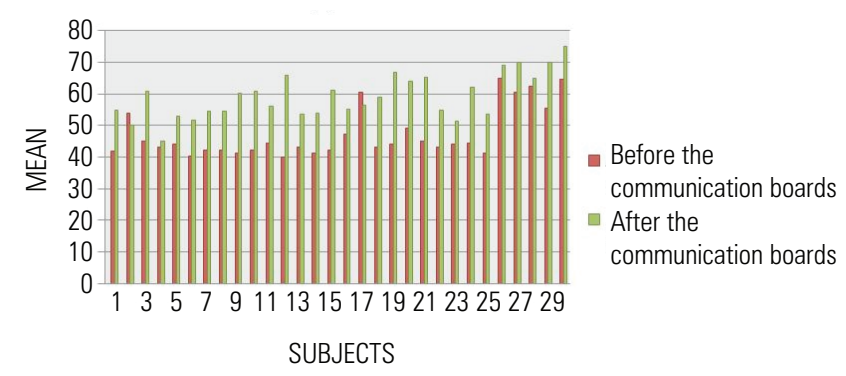

Figure 2. Vitality (V) - Before and after the communication board

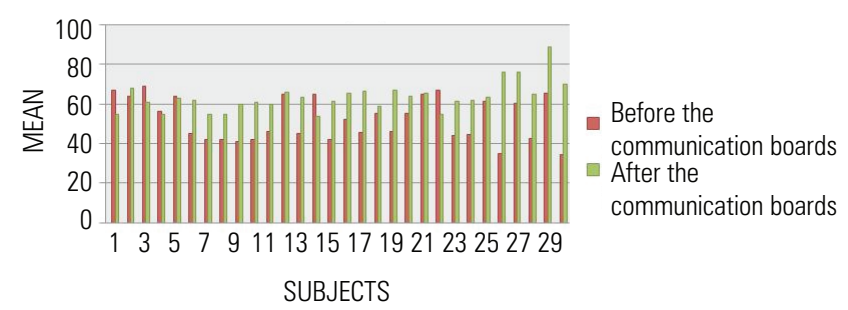

Figure 3. Social aspects (SA) - Before and after the communication board

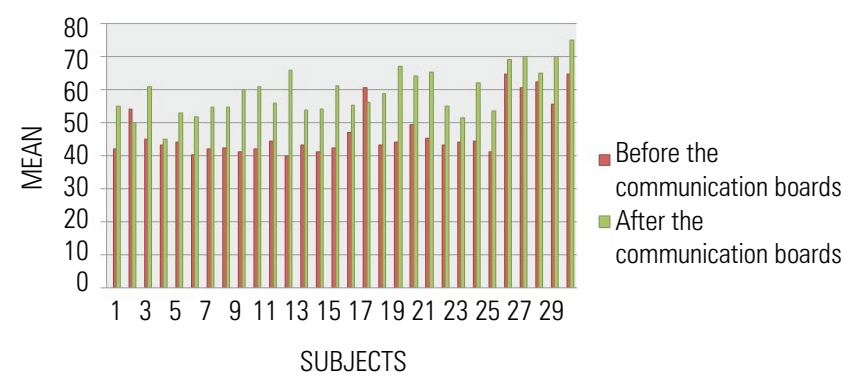

Figure 4. Limitations of the emotional aspects (LEA) - Before and after the communication board

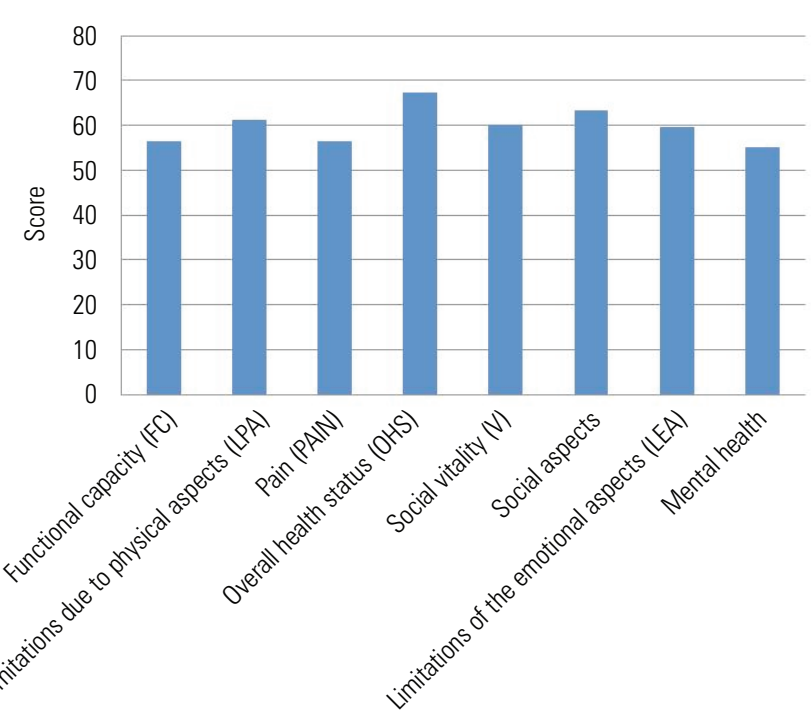

Figure 5. Score of SF-36 questionnaire

vitality" (V), and "limitations of the emotional aspects" (LEA) showed statistical significance after application of the boards (Table 2, Figures 2 to 4).

Figure 5 shows the overall results of the scores obtained in the various domains.

Upon analysis by Spearman's test, a correlation between the variables FCand LPA $(r=-0.28$; $\mathrm{p}=0.31$ ) was seen. Table 3 shows a positive and strong correlation between the variables $\mathrm{V}$ and LEA, indicating that the difficulties for vitality (V) and LEA are equivalent. 
In analyzing the scores of variables "pain" and "social aspects" (SA), Spearman's test indicated no significant correlation $(r=0.26 ; p=0.34)$.

\section{DISCUSSION}

The predominance of the male gender, and the mean age found in the investigation correlated with epidemiological studies ${ }^{(14)}$. The study conducted by Hulka et al ${ }^{(14)}$ states that age bracket is a characteristic naturally associated with the use of hospital services due to its biological influence on morbimortality. In comparison with Garbinato et al. ${ }^{(15)}$, who carried out a population-based study ( $\mathrm{n}=1,954$ individuals) in the southern part of Brazil between the years 2002 and 2003, we noted that male subjects aged 60 years or more were hospitalized 4 times more than the others.

The results show changes in all the SF-36 questionnaire domains in all the patients evaluated. As to the domains V, SA, and LEA, the final mean values obtained among the subjects showed significant differences. This might be explained by the fact that physical therapy and speech therapy provide techniques that enhance the performance of normal activities, accelerating the patient's recovery, minimizing the effects of incapacity by correcting the inefficiency of specific muscles ${ }^{(16)}$, since communication through speech occurs naturally, from early development in childhood to full use in adulthood. Therefore, its complexity or the consequences of its loss, whether it be total or partial, temporary or definitive, is rarely pondered ${ }^{(17-19)}$.

To Menzomo ${ }^{(20)}$, the loss or decrease of function impedes or modifies the patient's capacity to live, regardless of continuing his/her work. Another literary report affirms that therapeutic exercise consists in restoring, improving, or maintaining one or more characteristics related to the muscle as to its strength, stretching, and coordination ${ }^{(21)}$.

The strong association among the variables $\mathrm{V}, \mathrm{SA}$, and LEA, may suggest that the difficulties in feeding and communication are equivalent ${ }^{(22)}$. It confirms that dysarthria affects most of the individuals, as a result of atrophy and weakness of the muscles of the face, tongue, pharynx, and larynx.

In general, the intubation and tracheostomy procedures provoke motor disorders involving the structures responsible for producing speech and voice (phono-articulation) and swallowing ${ }^{(23)}$. Dysphagia that occurs after prolonged intubation may be related to numerous factors, such as the reduction of the alertness level due to residual effects of sedation, presence of a feeding tube, sensitivity alterations of the oropharynx and larynx, muscle atrophy provoke by lack of use, suppression of the protective reflexes of coughing, and alterations of the swallowing reflex ${ }^{(24)}$.
By means of laryngoscopy evaluation, Postma et al. ${ }^{(25)}$ observed a high incidence of laryngopharyngeal alterations in previously intubated patients, and these were greater with the increase in time of permanence of the tube. Laryngeal lesions after orotracheal intubation (OTI) may be a result of traumatic placement of the tube, need for prolonged mechanical ventilation, and patient agitation causing friction of the tube against the laryngeal mucosa or by the mere presence of the tube. Kunigk et al. ${ }^{(23)}$ highlighted that phono-articulation and swallowing processes are considered oromotor functions controlled by the same neural mechanisms, hindered by the sensorymotor control of the structures involved and required for both functions. This is manifested by difficulty in chewing and swallowing, frequent choking, resulting in decreased food consumption, weight loss, and aspiration pneumonia. The swallowing mechanism depends on a complex activation of neural circuits that require a harmonic execution involving the integrity of the afferent, efferent, sensitive, and motor pathways. Thus, the presence of a nervous dysfunction may lead to changes in neuromotor control, causing neurogenic dysphagia with specific symptoms ${ }^{(24,26)}$.

There was no significant correlation between the domains of "pain" and SA, demonstrating that pain hampers patients in their social relationships, leading to dullness, and thus, may be reflected the patient's emotional state. During the application of the quality of life test, it was noted that most patients were communicative, with a relatively good sense of humor, and were accompanied by family members that supported them during the data gathering procedure for this study.

Studies have shown that patients who have been hospitalized in the ICU go through an experience with great potential for trauma, and that many of them develop severe emotional conditions, including the post-traumatic stress syndrome. These experiences are accompanied by psychological distress that has negative repercussions in the overall rehabilitation of the patient.

The role of the physical therapist, along with the speech therapist, within a multidisciplinary team is vitally important for the ICU patient. Many times, joint intervention may be restricted to orientation of the staff and family regarding the patient's capacity to communicate, and the best way to establish contact with $\mathrm{him} /$ her. Even in this situation, there is considerable gain for the team and the family, with the understanding of what is going on in terms of communication, and consequently, a decrease in anxiety and stress, avoiding frustrating situations for the patient, the family, and the team that assists them. 


\section{CONCLUSION}

The evaluation of quality of life of the patients studied was better after the application of the communication boards, demonstrating the importance and need for communication between the staff and the patient, and the patient and family members.

\section{REFERENCES}

1. Mendes FC. A mediação da linguagem falada e da escrita: uma alternativa para superar as falhas na formação do professor [dissertação]. Brasília (DF): Universidade Católica de Brasília; 2001.

2. Neri M. Retrato da deficiência. Rio de Janeiro: Fundação Getúlio Vargas; 2003.

3. Pelosi MB. Inclusão e tecnologia assistida [dissertação]. Rio de Janeiro (RJ): Faculdade de Educação da Universidade do Estado do Rio de Janeiro; 2008.

4. Nunes LR. Linguagem e comunicação alternativa [dissertação]. Rio de Janeiro (RJ): Faculdade de Educação da Universidade do Estado do Rio de Janeiro; 2002.

5. Gonçalves MJO. Significado da comunicação no atendimento ao paciente em UTI: como o fonoaudiólogo pode ajudar. Mundo da Saúde. 2008:32(1):79-84.

6. Costello JM. Intervention in the Intensive Care Unit: The Children's Hospital Boston Model. AAC. 2000;16(3):137-53.

7. American Speech-Language-Hearing Association Ad Hoc Committee on Communication Processes and Non-speaking Persons. Position statement on nonspeech communication. ASHA. 1981;23(8):577-81.

8. Gava ML. AAC-Comunicação aumentativa e alternativa como resposta às deficiências verbais. In: Tupy TM, Pravettoni DG, organizadores. E se falta a palavra, qual comunicação, qual linguagem? São Paulo: Memnon; 1999. p. 79-99.

9. Hemsley B, Sigafoos J, Baladin S, Forbes R, Taylor C, Green VA, et al. Nursing the patient with severe communication impairment. J Advan Nurs. 2001;35(6):827-35.

10. Ware JE Jr, Sherbourne CD. The MOS 36-item short-form health survey (SF-36). I. Conceptual framework and item selection. Med Care. 1992;30(6):473-83.

11. Pereira MG. Epidemiologia teoria e prática. 8a ed. Rio de Janeiro: Guanabara Koogan; 2005.
12. Ciconelli RM. Tradução para o português e validação do questionário genérico de avaliação de qualidade de vida "Medical Outcomes Study 36-Item ShortForm Health Survey (SF-36)" [tese]. São Paulo: Universidade Federal de São Paulo;1997.

13. Martinez MC. As relações entre a satisfação com aspectos psicossociais no trabalho e a saúde do trabalhador [dissertação]. São Paulo: Faculdade de Saúde Pública da Universidade de São Paulo; 2002.

14. Hulka BS, Wheat JR. Patterns of utilization. The patient perspective. Med Care. 1985;23(5):438-60.

15. Garbinato LR, Béria JU, Figueiredo ACL, Raymann B, Gigante LP, Palazzo LS, et al. Prevalência de internação hospitalar e fatores associados: um estudo de base populacional em um centro urbano no Sul do Brasil. Cad Saude Publica. 2007;23(91):217-24.

16. Honsinger M, Yorkston K, Dowden P. Communication options for intubated patients. Respir Manag. 1987;17(3):45-52.

17. Hudelson E. Mechanical ventilation from the patient's point of view. Respir Care. 1997;22(6):654-6.

18. Menzel L. Need for communication related research in mechanically ventilated patients. Am J Crit Care. 1994;3(3):165-7

19. Mitsuda PM, Baarslag-Benson R, Hazel K, Therriault TM. Augmentative communication in intensive care unit settings. In: Yorkston KM, editor. Augmentative communication in the medical setting. Tucson, AZ: Communication Skill Builders; 1992. p.5-56.

20. Mezomo JC. Gestão da qualidade na saúde. Princípios básicos. São Paulo: Terra; 1995.

21. Shestack R. Fisioterapia prática. 3a ed. São Paulo: Manole; 1987.

22. Maschka DA, Bauman NM, Mccray PB, Hoffman HT, Karnell MP, Smith RJH. A classification scheme for paradoxical vocal cord motion. Laryngoscope. 1997;107(11 Pt 1):1429-35.

23. Kunigk MRG, Chehter E. Disfagia orofaríngea em pacientes submetidos à entubação orotraqueal. Rev Soc Bras Fonoaudiol. 2007;12(4):287-91.

24. El Solh A, Okada M, Bhat A, Pietrantoni C. Swallowing disorders post orotracheal intubation in the elderly. Intensive Care Med. 2003;29(9):1451-5.

25. Postma GN, McGuirt WF Sr, Butler SG, Rees CJ, Crandall HL, Tansavatdi K. Laryngopharyngeal abnormalities in hospitalized patients with dysphagia. Laryngoscope. 2007;117(10):1720-2.

26. Terré $\mathrm{R}$, Mearin F. Prospective evaluation of oro-pharyngeal dysphagia after severe traumatic brain injury. Brain Inj. 2007;21(13-14):1411-7. 